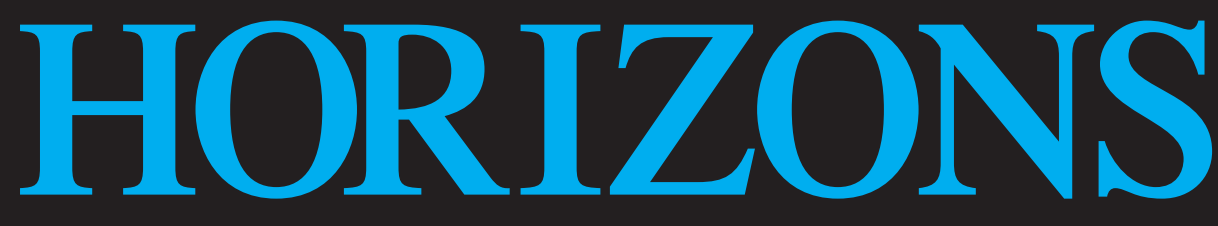

Volume 32

Spring, 2005

Number 1

\title{
ARTICLES
}

Brian W. Hughes, The Contemplative Function of Theology within Liberal Education: Rereading Newman's Idea of a University

Florence Caffrey Bourg, The Dual Vocation of Parenthood and Professional Theology

Peter C. Phan, Ignacio Ellacuría, S.J. in Dialogue with Asian Theologians

Ma. Christina A. Astorga, Ignatian Discernment

John W. Romanowsky, "When the Son of Man is Lifted Up": The Redemptive Power of the Crucifixion in the Gospel of John

EDITORIAL ESSAY

William L. Portier, Confessions of a Fractured Catholic Theologian

\section{EDITORIAL SYMPOSIUM}

Christopher M. Bellitto, Teaching the Church's Mistakes: Historical Hermeneutics in Memory and Reconciliation: The Church and the Faults of the Past

Bernard P. Prusak, Theological Considerations-Hermeneutical, Ecclesiological, Eschatological regarding Memory and Reconciliation: The Church and the Faults of the Past

\section{REVIEW ESSAY}

Edward Jeremy Miller, Reflections on the Role of Hans Küng, Occasioned by His Memoir, My Struggle for Freedom

Plus Reviews of 24 Books 


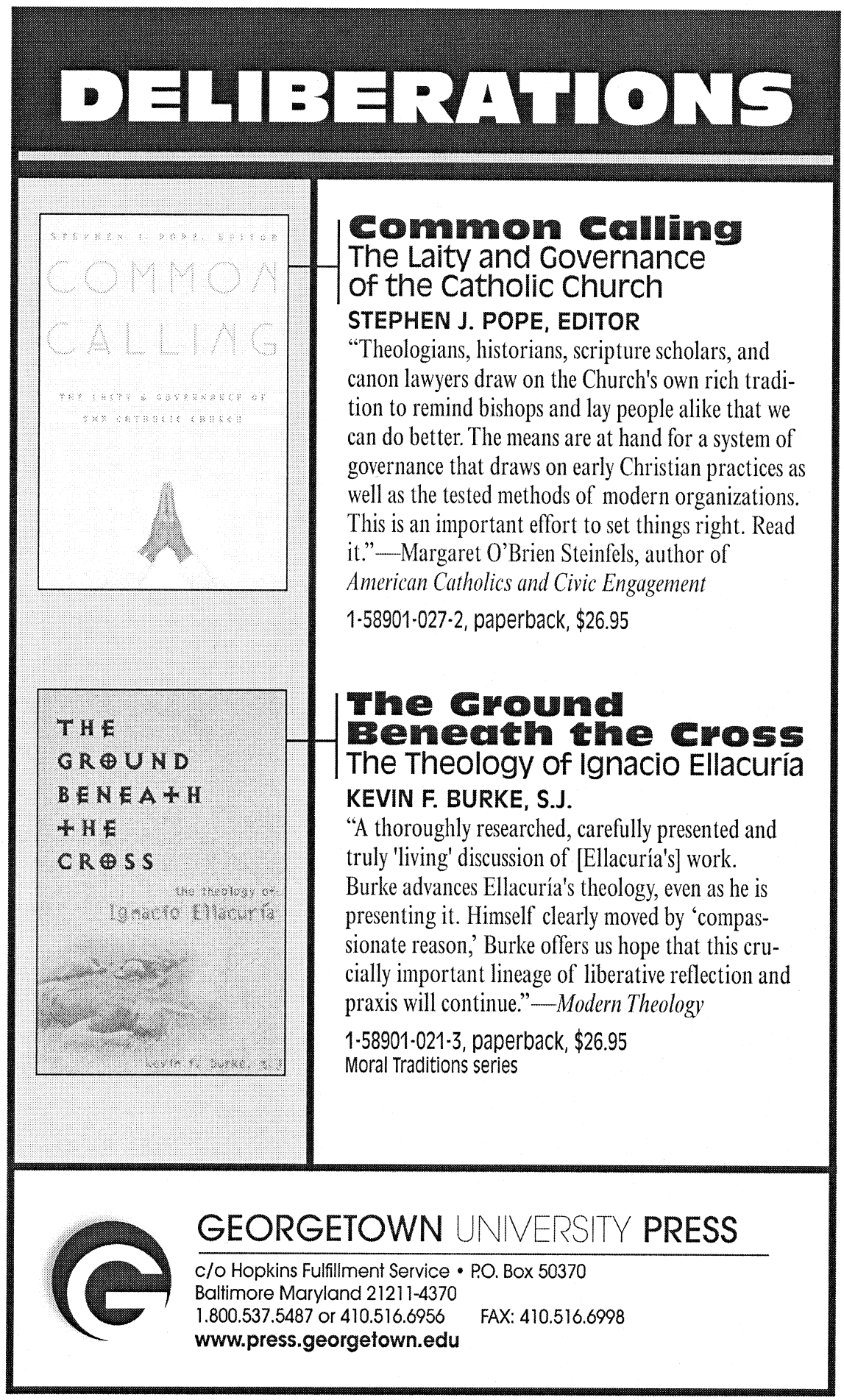




\title{
HORIZONS
}

\section{The Journal of the College Theology Society}

\author{
Published at Villanova University
}

Volume 32

Spring, 2005

Number 1

\section{ARTICLES}

The Contemplative Function of Theology within

Liberal Education: Rereading Newman's Idea of

a University Brian W. Hughes

The Dual Vocation of Parenthood and Professional

Theology: How are we Doing? Where are we Headed?

Ignacio Ellacuría, S.J. in Dialogue with

Asian Theologians: What Can They Learn

from each Other?

Peter C. Phan

Ignatian Discernment: A Critical

Contemporary Reading for Christian

Decision Making

Ma. Christina A. Astorga

"When the Son of Man is Lifted Up": The

Redemptive Power of the Crucifixion in the

Gospel of John John W. Romanowsky

\section{EDITORIAL ESSAY}

Confessions of a Fractured Catholic Theologian William L. Portier

\section{EDITORIAL SYMPOSIUM}

Teaching the Church's Mistakes: Historical Hermeneutics in Memory and Reconciliation:

The Church and the Faults of the Past Christopher M. Bellitto

Theological Considerations-Hermeneutical, Ecclesiological, Eschatological regarding Memory and Reconciliation: The Church and the Faults of the Past Bernard P. Prusak

\section{REVIEW ESSAY}

Reflections on the Role of Hans Küng, Occasioned by His Memoir, My Struggle for Freedom Edward Jeremy Miller

\section{BOOK REVIEWS}

Elizabeth Teresa Groppe, Yves Congar's

Theology of the Holy Spirit 
Gordon D. Kaufman, In the Beginning . . .

Creativity John V. Apczynski 160

Carl E. Braaten and Robert W. Jenson, eds., Mary,

Mother of God Mary E. Hines

Mark A. Noll and Carolyn Nystrom, Is the

Reformation Over? An Evangelical Assessment of

Contemporary Roman Catholicism William M. Shea

162

Jeffrey VanderWilt, Communion with

Non-Catholic Christians: Risks, Challenges, and Opportunities Judith K. Schaefer, O.P. 164

Francis Oakley and Bruce Russett, eds.,

Governance, Accountability, and the Future

of the Catholic Church Rodger Van Allen

Beatrice Bruteau, ed., Jesus Through Jewish Eyes:

Rabbis and Scholars Engage an Ancient

Brother in a New Conversation Regina A. Boisclair 167 John C. England, ed., Asian Christian Theologies:

A Research Guide to Authors, Movements,

Sources. Vol. 1: Asian Region $7^{\text {th }}-20^{\text {th }}$ Centuries;

Asian Christian Theologies. Vol. 2: Southeast Asia;

Asian Christian Theologies. Vol. 3: Northeast Asia ..... Peter C. Phan 169

Peter C. Phan, Christianity with an Asian Face:

Asian American Theology in the Making Pham Thanh Vân

Sally Bruyneel and Alan G. Padgett, Introducing

Christianity Leonard J. Biallas

Eileen Flynn, Why Believe?: Foundations of

Catholic Theology William J. Collinge

Lawrence S. Cunningham, ed., John Henry

Newman: Heart Speaks to Heart: Selected

Spiritual Writings Walter E. Conn

Sarah Borden, Edith Stein Elizabeth E. Carr

Patrick T. McCormick, A Banqueter's Guide

to the All-Night Soup Kitchen of the

Kingdom of God Christopher Steck, S.J.

Tim Muldoon, Come to the Banquet: Nourishing

Our Spiritual Hunger Eilish Ryan

Mary Ann Cejka and Thomas Bamat, eds.,

Artisans of Peace: Grassroots Peacemaking

among Christian Communities Mary Elsbernd, O.S.F.

Judith A. Merkle, From the Heart of the Church:

The Catholic Social Tradition Stephen J. Casey 180

Todd A. Salzman, What are They Saying About

Catholic Ethical Method? Edward J. Peck

Michele M. Schumacher, ed., Women in Christ:

Toward a New Feminism Lillian Bozak-DeLeo 
Carol L. Winkelmann, The Language of Battered

Women: A Rhetorical Analysis of Personal

Theologies

Helena J. Czosnyska 184

Bonnie J. Miller-McLemore, Let the Children

Come: Reimagining Childhood from a

Christian Perspective

Diane M. Millis 185

Don S. Browning and Terry D. Cooper, Religious

Thought and the Modern Psychologies Lucy Bregman 186

BOOKS RECEIVED

188 


\section{HORIZONS}

\section{The Journal of the College Theology Society}

Horizons, The Journal of the College Theology Society is published biannually in Spring and Fall at Villanova University, Villanova, PA 19085.

Yearly subscription: individual \$16.00, institutional \$40.00. Send remittance, payable to College Theology Society, P.O. Box 465, Hanover, PA 17331. Changes of address should also be sent to this address. Horizons is automatically received through membership in the College Theology Society.

Manuscripts, editorial and business correspondence, book reviews, advertising copy, and orders for single issues (individual \$8.00, institutional \$20.00) should be addressed to The Editor, Horizons, St. Mary’s Hall, Villanova University, Villanova, PA 19085. Telephone: (610) 519-7302. E-mail: HORIZONS@VILLANOVA.EDU

In submitting manuscripts, please send four clear copies. Author's name should appear only on an unpaginated cover sheet, with address and essay's title. No other identifying reference to author should appear on the manuscript. All references to author's work in text or notes should be in the third person. Essay's title should appear at top of first page of text. Notes should be placed on separate sheets at end. Full double spacing should be used throughout, including indented quotations and notes. Top, bottom, and right-hand margins should be at least one inch; left-hand margins at least one-and-a-half. Manuscripts should be accompanied by an abstract of one hundred fifty words or less and an author vita of one hundred words or less. Authors should state that the manuscript will not be submitted to another journal until Horizons' evaluation is completed. Manuscripts will be returned if postage is supplied.

Articles appearing in Horizons are abstracted and indexed in: The Catholic Periodical and Literature Index; Guide to Social Science and Religion in Periodical Literature; Index to Religious Periodical Literature; New Testament Abstracts; Religious and Theological Abstracts; and Social Science Citation Index. Articles are indexed in Religion Index One: Periodicals; book reviews indexed in Index to Book Reviews in Religion. Horizons is available in microform from Bell \& Howell, 300 North Zeeb Road, P.O. Box 1346, Ann Arbor, MI 48106-1346. It is also available on line in full text to ATLAS subscribers.

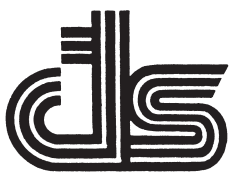

\section{COLLEGE THEOLOGY SOCIETY}

The College Theology Society is a professional organization of college and university professors of religion in the United States and Canada.

The purpose of the College Theology Society is to improve the quality of the teaching of religion: by stimulating and sharing scholarly research; by developing programs of theology and religious studies which meet student needs and interests; and by exploring, evaluating, and encouraging effective ways of teaching which are interdisciplinary and ecumenical.

Annual membership dues in the Society are \$50.00 (Full Professional or Associate), \$50.00 (Joint Professional for husband and wife), and \$25.00 (Graduate Student). Membership in the Society includes a subscription to Horizons. Contact Elena Procario-Foley, Religious Studies, Iona College, 715 North Ave., New Rochelle, NY 10801. Telephone: (914) 637-2744. E-mail: EProcariofoley@iona.edu 


\section{EDITORS}

Walter E. Conn Villanova University
Anthony J. Godzieba

Villanova University

\section{ASSOCIATE EDITORS}

Lisa Sowle Cahill

Boston College

Denise Lardner Carmody

Santa Clara University

Anne Carr

University of Chicago

Bernard Cooke

College of the Holy Cross (Emeritus)

Lawrence S. Cunningham

University of Notre Dame

Charles E. Curran

Southern Methodist University

Margaret A. Farley

Yale Divinity School

Elisabeth Schüssler Fiorenza

Harvard Divinity School

Francis Schüssler Fiorenza

Harvard Divinity School
Mary Ann Hinsdale

Boston College

Elizabeth A. Johnson

Fordham University

Paul F. Knitter

Xavier University (Emeritus)

Pheme Perkins

Boston College

Sandra M. Schneiders, I.H.M. Jesuit School of Theology at Berkeley

William M. Shea

Saint Louis University

Gerard S. Sloyan

Temple University (Emeritus)

William Thompson-Uberuaga

Duquesne University

David Tracy

University of Chicago

Mary Jo Weaver

Indiana University

BOOK REVIEW EDITORS

Joann Wolski Conn

Neumann College

Eileen Flanagan

Neumann College

\section{BUSINESS EDITOR}

Ellen Murray, R.S.M.

Gwynedd-Mercy College

EDITORIAL ASSISTANT

Irene C. Noble 


\section{HORIZONS}

\section{The Journal of the College Theology Society}

A journal exploring developments in Catholic theology, the total Christian tradition, human religious experience, and the concerns of creative teaching from the college and university environment.

John, Ignatius, Newman, Ellacuría, and parents in theology: there you have the makings for a serious puzzle of theological integrationnot to mention geographical. Brian Hughes brings us back to John Henry Newman to consider "The Contemplative Function of Theology within Liberal Education.” Florence Bourg investigates "The Dual Vocation of Parenthood and Professional Theology." Then we have dual Ignatian articles on dialogue and discernment. Peter Phan puts "Ignacio Ellacuría, S.J. in Dialogue with Asian Theologians" and Christina Astorga offers a contemporary reading of "Ignatian Discernment." Our final Article has John Romanowsky turning to John's Gospel on crucifixion and redemption: "When the Son of Man is Lifted Up."

Our Editorial Essay features William Portier making his "Confessions of a Fractured Catholic Theologian" upon installation in his new chair at the University of Dayton. And our Editorial Symposium pairs papers by Christopher Bellitto and Bernard Prusak on Memory and Reconciliation from the 2004 CTSA convention.

In our Review Essay Edward Miller reflects on Hans Küng in light of his recent memoir, My Struggle for Freedom. Finally, our Book Review Editors present reviews of twenty-four new titles.

-Walter E. Conn 